\title{
Acoustics suggests hidden diversity in Scinax garbei (Anura: Hylidae)
}

\author{
André Gomes Lopes, ${ }^{1,2}$ Davi Lee Bang, ${ }^{1,2,3}$ Pedro Marinho, ${ }^{1,2}$ and Ariovaldo Antonio Giaretta ${ }^{1}$ \\ ${ }^{1}$ Laboratório de Taxonomia e Sistemática de Anuros Neotropicais, Instituto de Ciências Exatas e Naturais do Pontal, \\ Universidade Federal de Uberlândia. 38304-402, Ituiutaba, MG, Brazil. E-mail: gomesandrebio@gmail.com. \\ ${ }^{2}$ Departamento de Biologia/FFCLRP, Programa de Pós-Graduação em Biologia Comparada, Universidade de São Paulo. 14040- \\ 901, Ribeirão Preto, SP, Brazil. \\ ${ }^{3}$ Laboratório de Zoologia de Vertebrados, Faculdade de Filosofia, Ciências e Letras de Ribeirão Preto (FFCLRP), Universidade \\ de São Paulo. 14040-901, Ribeirão Preto, SP, Brazil.
}

\begin{abstract}
Acoustics suggests hidden diversity in Scinax garbei (Anura: Hylidae). Scinax garbei is a treefrog species thought to be widely distributed across forest habitats of the Amazon Basin, occurring in Venezuela, Colombia, Ecuador, Peru, Bolivia, and Brazil. However, the morphological, acoustic and molecular characters of this species vary across its distribution. In view of this variation, the present study re-analyzes published advertisement calls and analyses new call data of nine populations of $S$. garbei from five countries, aiming to assess acoustic divergence. In addition, the territorial call of the species is described for the first time. Based on multivariate analyses of advertisement call data, there are three groups of populations with distinct calls, referred to herein as $S$. garbei Brazil, Northwestern, and Southwestern. Scinax garbei Northwestern is distinguished from $S$. garbei Southwestern by temporal call traits, whereas $S$. garbei Brazil differs from the other two groups based on both temporal and spectral traits. These results indicate that $S$. garbei may represent a complex of up to three species, thereby highlighting the need for a thorough taxonomic revision of this species.
\end{abstract}

Keywords: Amazonia, Amphibia, bioacoustics, Scinax rostratus Group, species complex, taxonomy.

\footnotetext{
Resumo

Acústica sugere diversidade oculta em Scinax garbei (Anura: Hylidae). Scinax garbei é uma espécie de anuro arborícola tida como amplamente distribuída pelos habitats florestais da Bacia Amazônica, ocorrendo na Venezuela, Colômbia, Equador, Peru, Bolívia e Brasil. No entanto, os caracteres morfológicos, acústicos e moleculares dessa espécie variam ao longo da sua distribuição. Diante dessa variação, o presente estudo reanalisa cantos de anúncio publicados e novos dados de cantos de nove populações de $S$. garbei de cinco países, para avaliar a divergência acústica. Além
}

Received 02 August 2019 


\begin{abstract}
disso, o canto territorial da espécie é descrito pela primeira vez. Com base em análises multivariadas de dados de cantos de anúncio, existem três grupos de populações com cantos distintos, referidas aqui como S. garbei Brasil, Noroeste e Sudoeste. Scinax garbei Noroeste se distingue de S. garbei Sudoeste com base em traços temporais do canto, enquanto que $S$. garbei Brasil se distingue dos outros dois grupos com base em ambos traços temporais e espectrais do canto. Esses resultados indicam que $S$. garbei pode representar um complexo de até três espécies, destacando, portanto, a necessidade de uma minuciosa revisão taxonômica dessa espécie.
\end{abstract}

Palavras-chave: Amazônia, Amphibia, bioacústica, complexo de espécies, grupo de Scinax rostratus, taxonomia.

\section{Introduction}

The Neotropics harbor the greatest frog diversity in the world, especially in South America (Duellman 1999, Villalobos et al. 2013). However, this species richness currently is underestimated given the existence of many complexes of morphologically cryptic species, particularly in the Amazonian region (e.g., Fouquet et al. 2007, 2016, Funk et al. 2011, Ferrão et al. 2016, Caminer et al. 2017, Vacher et al. 2017, 2020, Rivadeneira et al. 2018, Chasiluisa et al. 2020, Mota et al. 2020). In this context, integrative approaches that incorporate distinct lines of evidence (e.g., acoustics, molecular, cytogenetics, etc.) have effectively solved taxonomic problems (e.g., Padial and De la Riva 2009, Caminer and Ron 2014, 2020, Baldo et al. 2019).

Frogs emit different types of acoustic signals that are categorized based on the social context in which the vocalizations are made (Toledo et al. 2015, Köhler et al. 2017). The most common type is the advertisement call; this is emitted by males to attract conspecific females and maintain between-males spacing in a chorus (Duellman and Trueb 1994, Wells 2007, Toledo et al. 2015, Köhler et al. 2017). As this call transmits species-specific information related to prezygotic isolation (Köhler et al. 2017), it is a useful diagnostic tool to reveal morphologically cryptic species (e.g., Nunes et al. 2012, Ron et al. 2018, Carvalho et al. 2019). Another common acoustic signal is the territorial call, which is emitted in aggressive contexts that involve the defense of a territory (e.g., calling site) (Toledo et al. 2015, Köhler et al. 2017).

Scinax Wagler, 1830 currently comprises 72 species of treefrogs distributed throughout the Neotropics (Frost 2020). Scinax garbei (MirandaRibeiro, 1926) is a large-sized species of the $S$. rostratus Species Group (Faivovich 2002, Faivovich et al. 2005, Wiens et al. 2010), described from the Rio Juruá, Eirunepé, state of Amazonas (AM), Brazil. This species is thought to be widely distributed across forest habitats of the Amazon Basin, with occurrences reported from Venezuela, Colombia, Ecuador, Peru, Bolivia (La Marca 1992, Duellman and Wiens 1993, De la Riva et al. 1994, Barrio-Amorós et al. 2019), and from the Brazilian states of Acre (Bernarde et al. 2011, 2013), Amapá (Silva e Silva and Costa-Campos 2014), Amazonas (Miranda-Ribeiro 1926, Lima et al. 2006, Pantoja and Fraga 2012), Mato Grosso (SãoPedro et al. 2009, Noronha et al. 2015, present study), Pará (Ávila-Pires et al. 2010, Pinheiro et al. 2012), and Rondônia (Bernarde 2007, Piatti et al. 2012).

Some of the advertisement calls of Scinax garbei from populations in Ecuador, Peru, and Bolivia differ markedly from one another (Duellman 1970, 1972, 1978, 2005, Duellman and Pyles 1983, Duellman and Wiens 1993, De la Riva et al. 1994). Although Zimmerman (1983) reported the dominant frequency and pulse rate for a specimen from Manaus (AM), the advertisement call of $S$. garbei never has 
been formally described from Brazil. Moreover, the species varies considerably in body size, thigh color pattern, and degree of development of the proboscis and of the heel tubercle (Duellman 1970, 1972, Heyer 1977, Duellman and Wiens 1993). In addition, recent molecular studies have shown that the populations from Ecuador and southeastern Peru do not form a monophyletic group (Jansen et al. 2011; Ron et al. 2018). These inconsistencies suggest that $S$. garbei represents a species complex, thereby illustrating the need of a better assessment of the taxonomic status of the different populations currently under this name.

Call divergences between some populations of Scinax garbei may elucidate their respective identities. However, many of the apparent discrepancies may reflect the different technologies and methodologies used in the analyses of calls; thus, reliable comparisons cannot be made. Herein, we re-analyze published data and also analyze original recordings of $S$. garbei from a total of nine populations from five countries. Acoustic variation among some populations is discussed, as well as the taxonomic implications of the observed variation. Lastly, we provide the first description of the territorial call of the species.

\section{Materials and Methods}

\section{Data Collection}

Vocalizations were recorded on two occasions: (1) on 24 January 2011 on the Campus of the Universidade Federal do Amazonas, Manaus, state of Amazonas (AM), northern Brazil (0306'0.86" S, 59 58'35.59" W, 79 m a.s.1., datum WGS84; ca. 1,170 km eastnortheast of the type locality of Scinax garbei); and (2) on 11 January 2019 in the municipality of Alta Floresta, state of Mato Grosso (MT), Brazil (09³8'34.22" S, 56¹6'17.07" W, 273 m a.s.1., datum WGS84; ca. 1,540 km east-southeast of the type locality).
Specimens collected in Alta Floresta are housed in the Collection of Frogs of the Museu de Biodiversidade do Cerrado, Universidade Federal de Uberlândia (AAG-UFU 6498-6502, with specimens 6498 and 6499 being call vouchers). Recordings (sampling rates of 44.1 or $48.0 \mathrm{kHz} ; 16$ bits resolution) are also deposited in the same collection. See Appendix I for further details about recordings.

\section{Additional Recordings}

Fourteen recordings from the following localities were provided by the Fonoteca Zoologica (FonoZoo) from the Museo Nacional de Ciencias Naturales de Madri: Puerto Almacén (Bolivia), Abel Iturralde Province (Bolivia), Leticia (Colombia), Pucaurquillo (Peru), Pilcopata (Peru), and Santa Cecilia (Ecuador). Vocalizations of Scinax garbei from some of these localities had been analyzed previouslye.g., Pilcopata (Duellman 1972, Duellman and Wiens 1993), Santa Cecilia (Duellman 1970, 1972, 1978, Duellman and Wiens 1993), and Puerto Almacén (De la Riva et al. 1994). One voucher specimen from Pilcopata and two from Santa Cecilia are housed in the KU Herpetology Collection of the Biodiversity Institute at the University of Kansas (respectively KU 139242, $125603,125604)$. These recordings were made with analogue recorders and digitized at a sampling rate of at least $44.1 \mathrm{kHz}$ and 16 bits resolution. A recording from TambopataCandamo National Park (Peru) published on a CD by Cocroft et al. (2001) also was analyzed. Appendix I provides recording details.

\section{Specimen Identification}

Voucher specimens from Santa Cecilia and Pilcopata were identified as Scinax garbei by Duellman $(1970,1972)$ and Duellman and Wiens (1993). We confirmed the identity of other recordings attributed to $S$. garbei based on the similarity of the advertisement call to those of either of these two populations. Based on the 
resemblance of the advertisement calls, we determined that the recording from Manaus was of the same species as that from Alta Floresta. Characters of the frogs from Alta Floresta match the diagnosis provided for $S$. garbei by Duellman and Wiens (1993), as follow: (1) snout-vent length (SVL) 41.4-44.0 mm [mean: 42.9; standard deviation (SD): 1.1]; (2) snout acuminate in dorsal and lateral profiles, with a proboscis that present different degrees of development; (3) conical ulnar and tarsal tubercles present (more or less distinct); (4) enlarged heel tubercle present; (5) tubercles present on lower jaw; (6) skin on dorsum smooth to tuberculate, with tubercles often conical; (7) dorsum brown (brown or dull green in life), with dark triangular mark with apex directed posteriorly and corners on eyelids; (8) large dark marks posterodorsal to axillae; (9) dashes or transverse marks in sacral region; (10) transverse bars on dorsal surface of limbs; (11) flanks cream with brown flecks; (12) broad cream (orange in life) and dark vertical bars on posterior surfaces of thighs; and (13) iris pale creamy bronze, with a median horizontal reddish-brown streak.

\section{Acoustic Analyses}

A high-pass filter up to $500 \mathrm{~Hz}$ and a lowpass filter up to $5000 \mathrm{~Hz}$ were applied to recordings to reduce background noise. After filtering, recordings with low amplitude levels were normalized (peak -1.0 dB) with Audacity v. 2.2.2 software (Audacity Team 2020). Advertisement calls $(N=237)$ from nine populations and territorial calls $(N=97)$ from seven populations were analyzed in Raven Pro v. 1.5 software (Center for Conservation Bioacoustics 2014) with the following settings: window size $=256$ samples; $3 \mathrm{~dB}$ filter bandwidth $=248,270$ or $539 \mathrm{~Hz}$; window type = Hann; overlap = $89.8 \%$ (locked); hop size $=0.271,0.542$ or 0.590 ms; DFT size $=1024$ samples; grid spacing = 43.1, 46.9 or $93.8 \mathrm{~Hz}$ (depending on the sampling rate). Temporal traits were obtained from oscillograms. Dominant, maximum, and minimum frequency values were obtained through "Peak Frequency," "Frequency 95\%," and "Frequency $5 \%$ " functions of Raven, respectively. We used the acoustic terminology and definitions of Bang and Giaretta (2016) with the following exceptions. The call rate is that of Carvalho et al. (2017). Pulse rate was calculated from a section of $100 \mathrm{~ms}$ in the middle of the call, as follows: (number of pulses - 1) / time between the onset of first and last pulses. The callcentered approach of Köhler et al. (2017) was adopted. Mean and standard deviation (SD) values were obtained from mean values of each individual, whereas ranges (i.e., minimummaximum) include all values from the raw dataset. Sound figures were generated with the seewave package v. 1.7.6 (Sueur et al. 2008) in the R platform v. 3.5.2 (R Core Team 2018) with the following settings: window = Hanning, overlap $=85 \%$, and FFT $=256$.

\section{Classification of Call Types}

Two types of call were recognized. Advertisement calls are the most common, emitted repeatedly in a stereotyped way, and sometimes antiphonally by neighboring males (Köhler et al. 2017). Territorial calls (sensu Toledo et al. 2015) are those often emitted by males in close-range interactions in Alta Floresta. Advertisement and territorial calls from other recordings were categorized as such based on the context of the recording and by comparison with recordings from Alta Floresta.

\section{Statistical Analyses}

Multivariate analysis included all traits measured for call descriptions and were based on mean values of each individual. Among-population/groups acoustic discrimination was sought through the randomForest (RF) (randomForest v. 4.6-14 package, Liaw and Wiener 2002) and DAPC (Discriminant Analysis on Principal Components) (adegenet v. 2.1.1 package; Jombart 
2008, Jombart et al. 2010) functions in $\mathrm{R}$ platform. The RF algorithm constructs several (by default 500) classification trees using bootstrap samples from the original dataset, with each split using the best predictors among those randomly chosen at each node; then it generates classifiers and aggregates results by voting to classes (Breiman 2001, Liaw and Wiener 2002). Unsupervised (i.e., no pre-established groups) $\mathrm{RF}$ analyses were performed a priori to detect putative clustering among samples; subsequent multivariate analyses were carried over the recognized clusters. RF analyses also result in between-objects distance estimates, which are subject to a Multidimensional Scaling Analysis (MDS) and displayed graphically through the proximityPlot function (rfPermute package; Archer 2014). The DAPC runs on the Principal Component Scores (Jombart 2008, Jombart et al. 2010). A Discriminant Analysis (DA) was applied on a few axes (retaining ca. 95\% of the variance) of the Principal Component Analysis (PCA), improving the imbalance between objects and traits (Jombart et al. 2010). The DAPC analysis was carried out to test for reciprocal congruence between it and RF.

Traits indicated as important for amonggroups discrimination by RF and DAPC, were assessed for statistical significance with the "Exact Wilcoxon Mann Whitney Rank Sum Test", by applying the function wilcox_test (coin package; Hothorn et al. 2008) in R. As this test is performed between pairs, the significance levels $(p)$ were adjusted by the Holm method applying the p.adjust function. Statistical significance was assumed when $p$-value $<0.05$.

\section{Results}

Unsupervised RF analysis resulted in three clusters, hereinafter designated by their geographic location (Figure 1): (1) Scinax garbei Brazil.-Alta Floresta $(N=4$ males; 81 calls) and Manaus ( $N=1 ; 12)$; (2) Scinax garbei Southwestern.-Abel Iturralde $(N=2 ; 7)$, Puerto Almacén $(N=1 ; 20)$, Tambopata-Candamo
National Park $(N=1 ; 16)$, and Pilcopata $(N=3$; 7); and (3) Scinax garbei Northwestern.Pucaurquillo $(N=1 ; 6)$, Leticia $(N=1 ; 11)$, and Santa Cecilia $(N=6 ; 77)$.

\section{Descriptions of Vocalizations}

Advertisement calls.-Calls of all groups (Figures 2, 3) consist of a single multi-pulsed note composed of two emphasized frequency bands [hereinafter called lower (LFB) and higher (HFB) bands]. Calls of Scinax garbei Brazil and Southwestern have similar envelopes, with a fast-ascending amplitude modulation at the onset and quickly reaching a plateau that is sustained for the duration. Calls of S. garbei Northwestern have an irregular, elliptical envelope, with variation in amplitude modulation in the middle and final portions of the call; calls of frogs from Leticia lack this downward modulation. Calls of S. garbei Brazil and Southwestern have variable durations, whereas call duration of S. garbei Northwestern is more regular. First and final pulses have more variable durations and intervals; pulses of $S$. garbei Northwestern occasionally have deeper internal amplitude modulations (Figure 3). In both S. garbei Brazil and Southwestern, the HFB has a fast-upward modulation at the call onset and quickly reaches a stable frequency that is sustained for the duration of the call. In contrast, the HFB of $S$. garbei Northwestern has a long, gradual upward modulation from the call onset to some point at the middle or final portion, at which it reaches a stable frequency that is sustained for the call duration. Unlike HFB, the LFB of all groups maintains a stable frequency throughout the call. In all groups, the dominant frequency can alternate between the LFB and HFB along call emissions; it alternated between bands in three individuals of $S$. garbei Brazil, in two of $S$. garbei Southwestern, and in six of S. garbei Northwestern. Conversely, dominant frequency corresponds only to HFB in two $S$. garbei Brazil, in two $S$. garbei Southwestern, and in one $S$. garbei Northwestern. Also, in one S. garbei 




Figure 1. Distribution map of the three groups of Scinax garbei recognized here (ellipses: pink = S. garbei Brazil; green $=S$. garbei Northwestern; blue $=S$. garbei Southwestern). Star = type locality (Juruá River, Eirunepé); 1 = Alta Floresta; 2 = Manaus; 3 = Leticia; 4 = Pucaurquillo; $5=$ Santa Cecilia; $6=$ Pilcopata; $7=$ Tambopata; 8 = Abel Iturralde; 9 = Puerto Almacén. Abbreviations for Brazilian states: AC = Acre, AM = Amazonas, MT $=$ Mato Grosso, $\mathrm{RO}=$ Rondônia, RR = Roraima.

Northwestern, the dominant frequency corresponded only to LFB. Descriptive statistics of call traits of each group are in Table 1 and of each population in Appendix II.

Territorial calls._-These calls were emitted by individuals from all populations, except for those from Puerto Almacén and Tambopata. Calls of all groups (Figure 4) consist of a single multi-pulsed note with irregular amplitude modulations; usually there is an ascending amplitude modulation in the first part of the call and a downward modulation in the final portion. Calls of $S$. garbei Northwestern and Southwestern vary in duration, whereas call duration of $S$. garbei Brazil is more regular. Pulses in the middle portion of the call usually are better defined. Territorial calls often are emitted shortly after advertisement calls. However, these calls also are emitted without having been preceded by an advertisement call, and not all advertisement calls are followed by territorial ones $(52 \%$ of advertisement calls of $S$. garbei Brazil, $26 \%$ of S. garbei Southwestern, and $13 \%$ of $S$. garbei Northwestern were followed by territorial calls.) Territorial calls also have two main frequency bands in which dominant frequency alternates along call emissions. Descriptive statistics are in Table 2. 
Table 1. Advertisement call traits of the three groups of Scinax garbei recognized here. $N=$ number of individuals/ number of calls analyzed. Values are given as mean $\pm \mathrm{SD}$ (minimum-maximum).

\begin{tabular}{lccc}
\hline Call characteristics & $\begin{array}{c}\text { Brazil } \\
(N=5 / 93)\end{array}$ & $\begin{array}{c}\text { Northwestern } \\
(N=8 / 94)\end{array}$ & $\begin{array}{c}\text { Southwestern } \\
(N=7 / 50)\end{array}$ \\
\hline Duration (s) & $1.9 \pm 0.5(0.3-3.0)$ & $0.5 \pm 0.1(0.3-0.7)$ & $0.9 \pm 0.2(0.3-1.9)$ \\
Rate (calls/min) & $15.5 \pm 10.9(2.1-27.1)$ & $46.4 \pm 19.5(9.9-69.1)$ & $22.1 \pm 9.9(9.4-38.7)$ \\
Interval (s) & $4.0 \pm 6.4(0.4-69.7)$ & $1.5 \pm 2.0(0.2-30.0)$ & $2.3 \pm 2.0(0.5-7.8)$ \\
$1^{\text {st }}$ pulse duration (ms) & $5.3 \pm 1.0(2.0-11.0)$ & $6.3 \pm 1.7(3.0-17.0)$ & $7.4 \pm 1.3(3.0-12.0)$ \\
Mid-portion pulses duration $(\mathrm{ms})$ & $7.8 \pm 0.8(5.0-11.0)$ & $7.4 \pm 1.6(4.0-12.0)$ & $7.5 \pm 1.1(4.0-11.0)$ \\
Final pulse duration (ms) & $10.1 \pm 0.7(6.0-15.0)$ & $9.6 \pm 1.8(5.0-20.0)$ & $10.6 \pm 2.7(5.0-14.0)$ \\
$1^{\text {st }}$ pulse interval (ms) & $4.1 \pm 1.3(1.0-19.0)$ & $5.7 \pm 1.2(2.0-17.0)$ & $7.8 \pm 2.2(3.0-22.0)$ \\
Mid-portion pulse interval (ms) & $6.4 \pm 0.5(5.0-9.0)$ & $4.3 \pm 0.9(1.0-8.0)$ & $8.1 \pm 0.9(5.0-11.0)$ \\
Final pulse interval (ms) & $7.0 \pm 0.6(4.0-10.0)$ & $4.8 \pm 1.2(2.0-9.0)$ & $8.6 \pm 1.3(5.0-14.0)$ \\
Pulse rate (pulses/s) & $72.7 \pm 2.1(69.0-76.9)$ & $88.5 \pm 11.7(74.5-108.7)$ & $66.0 \pm 5.4(54.9-72.2)$ \\
Minimum frequency $(\mathrm{Hz})$ & $843 \pm 59(750-938)$ & $1304 \pm 48(1219-1406)$ & $1423 \pm 131(1292-1723)$ \\
Maximum frequency $(\mathrm{Hz})$ & $3289 \pm 228(2813-3703)$ & $3700 \pm 245(3230-4313)$ & $4165 \pm 393(3618-4996)$ \\
Dominant frequency of LFB (Hz) & $993 \pm 22(938-1219)$ & $1590 \pm 85(1464-1781)$ & $1644 \pm 99(1421-1781)$ \\
Dominant frequency of HFB (Hz) & $2903 \pm 125(2627-3188)$ & $3355 \pm 284(2756-4031)$ & $3475 \pm 165(3058-3876)$ \\
\hline
\end{tabular}

\section{Statistical Comparisons}

Supervised analysis of RF (Figure 5) of the main groups resulted in $0 \%$ error rate-i.e., recordings from all populations were recovered in their own groups. Scinax garbei Northwestern is completely discriminated from $S$. garbei Brazil along both axes; it is distinguished from $S$. garbei Southwestern along the first axis and slightly separate along the second axis. Scinax garbei Brazil and S. garbei Southwestern are completely separated along the second axis and overlap along the first axis. Likewise, DAPC analysis resulted in all individuals reassigned to their original clusters. In this discriminant analysis, S. garbei Northwestern and Brazil overlap along the second axis but are completely separated along the first axis; $S$. garbei Southwestern is separated from the other groups along both axes.
Six acoustic traits indicated by the multivariate analyses as important for discrimination have statistically significant differences (Figure 6; Table 3). Scinax garbei Brazil is diagnosed from $S$. garbei Southwestern by its longer call and lower dominant frequencies to both LFB and HFB. Scinax garbei Brazil is diagnosed from S. garbei Northwestern by its longer call, longer pulse intervals in the middle and final parts of the call, and by its lower pulse rate and dominant frequency of LFB. Scinax garbei Southwestern is diagnosed from $S$. garbei Northwestern by its longer pulse intervals in the middle and final parts of the call, and lower pulse rate.

\section{Discussion}

Published descriptions of the advertisement call of Scinax garbei are somewhat discordant. 
A

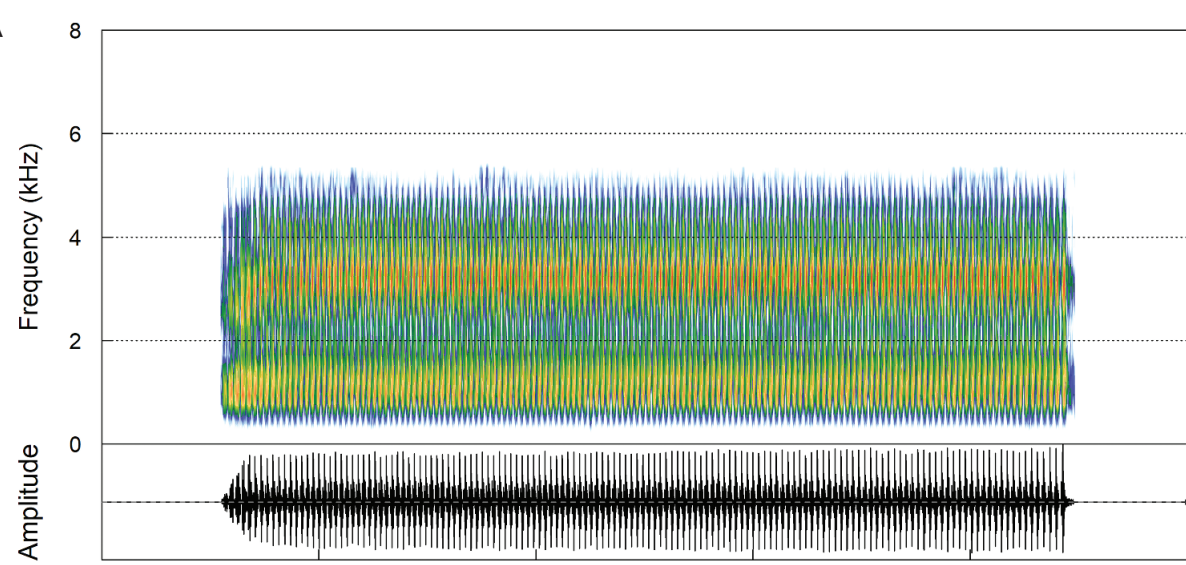

Amplitude (dB)

B

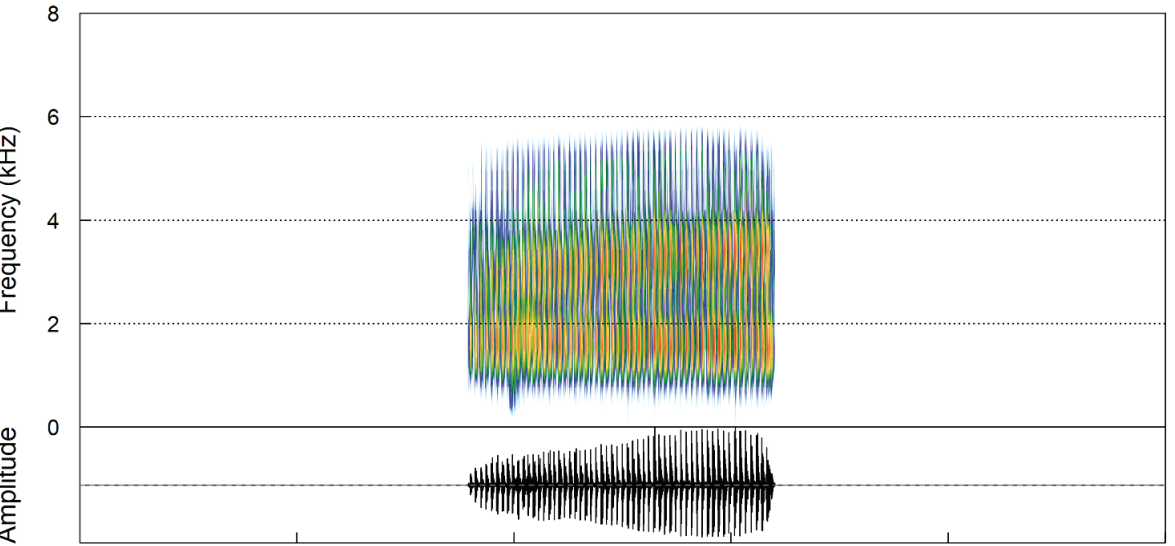

Amplitude (dB)

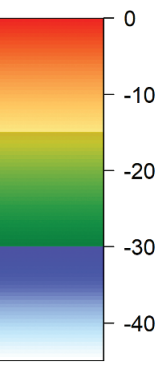

C

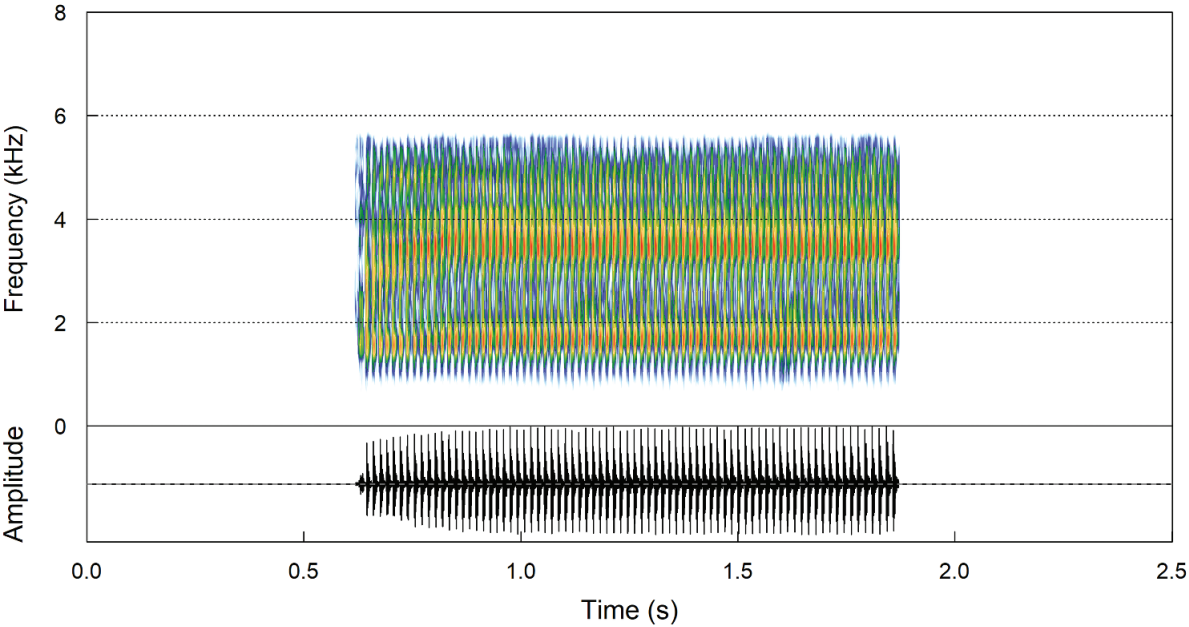

Amplitude (dB)

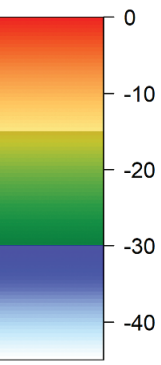

Figure 2. Audiospectrograms and respective oscillograms of the advertisement calls of Scinax garbei Brazil (A), Northwestern (B) and Southwestern (C). Sound files: Scinax_garbeiAltaFlorestaMT1bPM_AAGm671 (A); 7807 (FonoZoo) (B); Track 40 (CD Frogs of Tambopata) (C). Further recordings details are in Appendix I. 
A

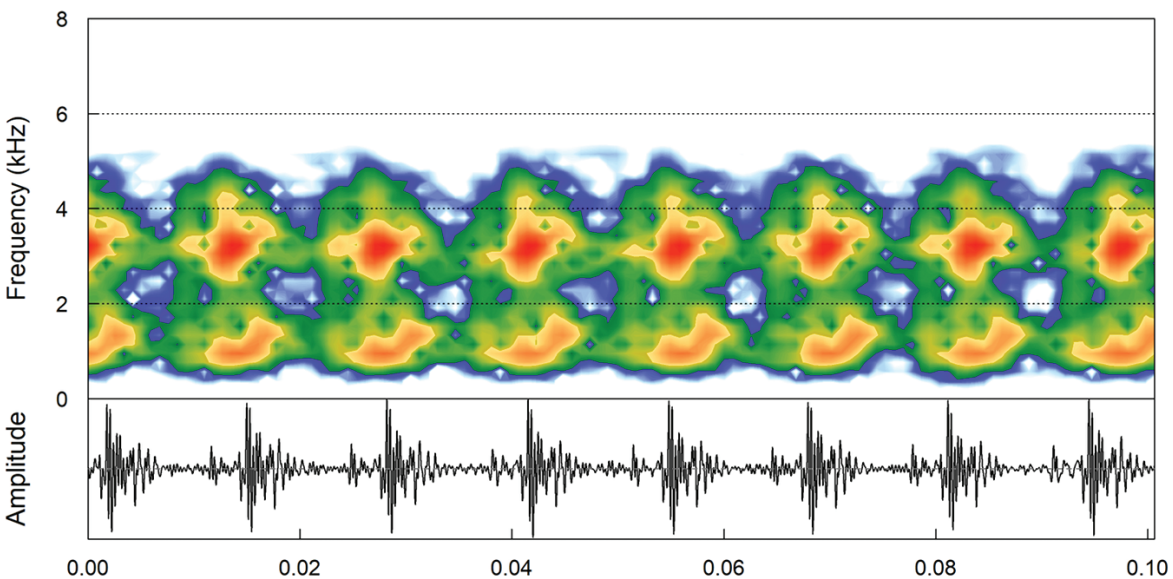

Amplitude (dB)
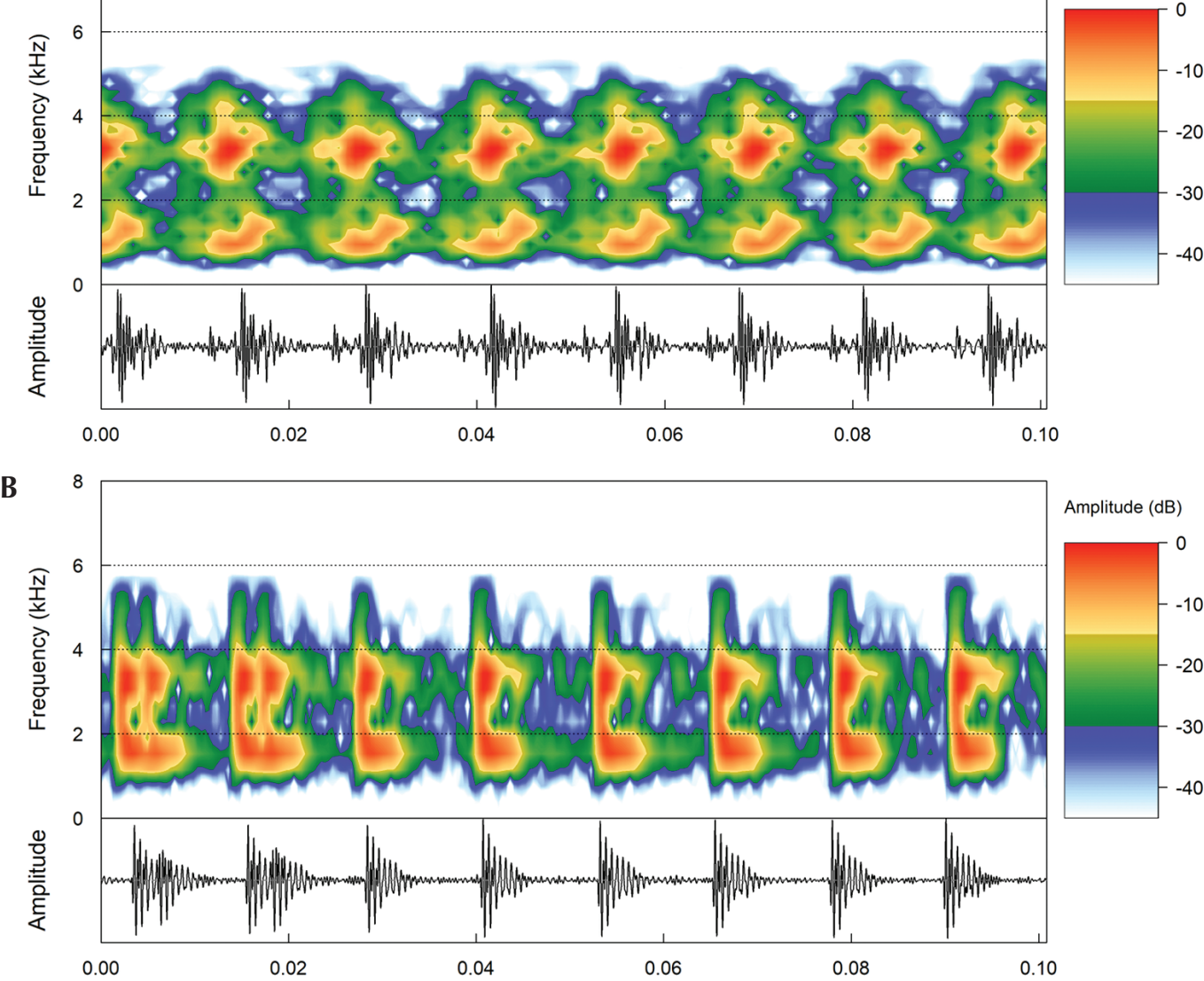

Amplitude (dB)

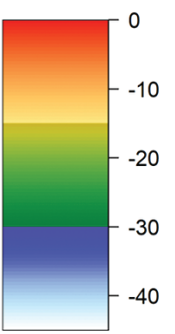

C

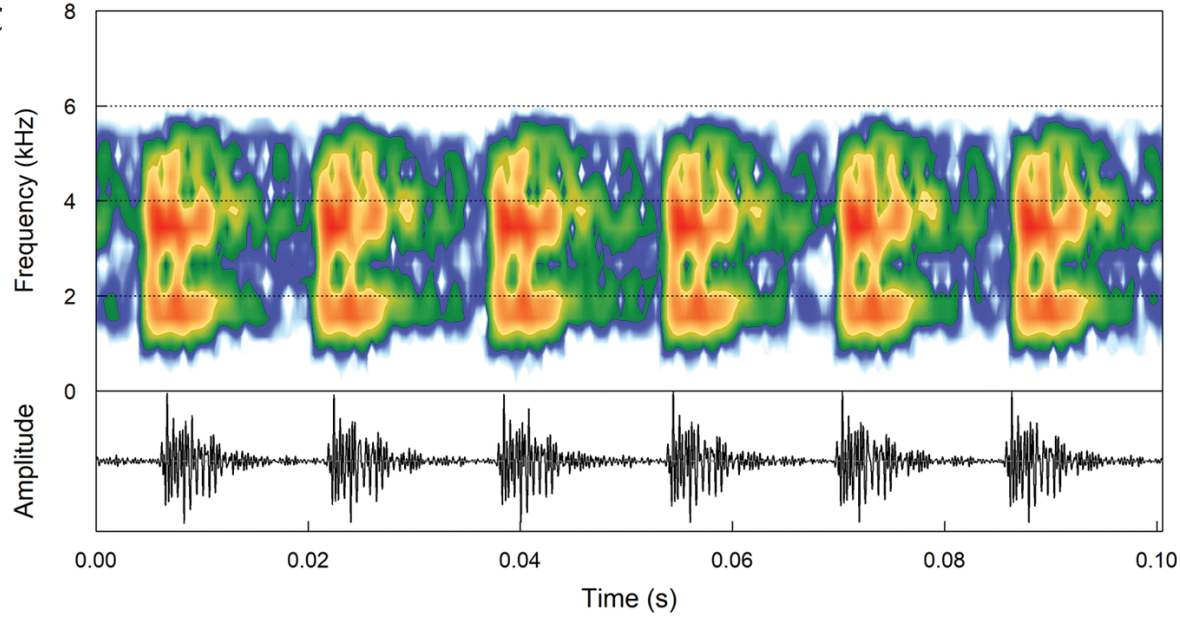

Amplitude (dB)

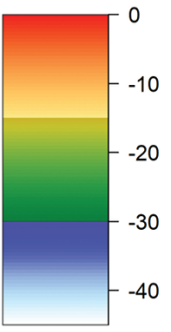

Figure 3. Audiospectrograms and respective oscillograms of 100-ms sections extracted from the midpoint of each call depicted in Figure 2, detailing pulses shape: Scinax garbei Brazil (A), Northwestern (B) and Southwestern (C). 
Table 2. Territorial call traits of the three groups of Scinax garbei recognized here. $N=$ number of individuals/number of calls analyzed. Values are given as mean \pm SD (minimum-maximum).

\begin{tabular}{lccc}
\hline Call characteristics & $\begin{array}{c}\text { Brazil } \\
(N=5 / 56)\end{array}$ & $\begin{array}{c}\text { Northwestern } \\
(N=6 / 17)\end{array}$ & $\begin{array}{c}\text { Southwestern } \\
(N=4 / 14)\end{array}$ \\
\hline Duration (s) & $0.045 \pm 0.008$ & $0.038 \pm 0.026$ & $0.057 \pm 0.020$ \\
& $(0.033-0.059)$ & $(0.013-0.102)$ & $(0.020-0.105)$ \\
Interval after advertisement call (s) & $0.031 \pm 0.004$ & $0.031 \pm 0.010$ & $0.017 \pm 0.010$ \\
& $(0.022-0.048)$ & $(0.003-0.076)$ & $(0.003-0.032)$ \\
Minimum frequency $(\mathrm{Hz})$ & $903 \pm 154$ & $1326 \pm 76$ & $1484 \pm 118$ \\
& $(750-1359)$ & $(1219-1500)$ & $(1335-1688)$ \\
Maximum frequency $(\mathrm{Hz})$ & $3385 \pm 299$ & $3879 \pm 350$ & $(3445-5063)$ \\
& $(3000-4091)$ & $(3469-4500)$ & $1693 \pm 195$ \\
Dominant frequency of LFB $(\mathrm{Hz})$ & $1050 \pm 190$ & $1631 \pm 79$ & $(1464-2063)$ \\
Dominant frequency of HFB $(\mathrm{Hz})$ & $(818-1723)$ & $(1378-1938)$ & $3345 \pm 147$ \\
\hline
\end{tabular}
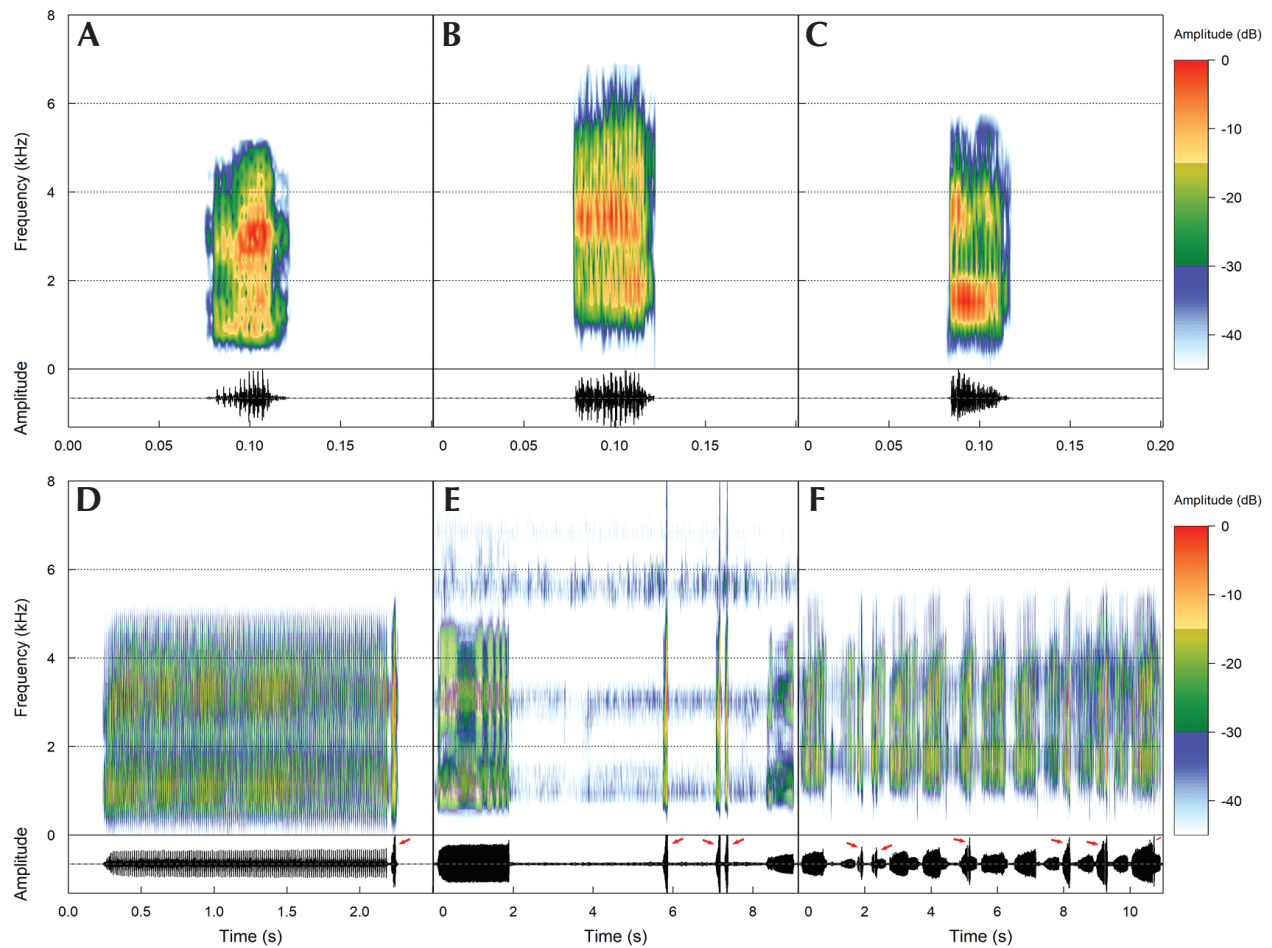

Figure 4. Audiospectrograms and respective oscillograms of the territorial call of Scinax garbei Brazil (A), Southwestern (B) and Northwestern $(\mathbf{C})$. Territorial call preceded by an advertisement call (D), and three territorial calls emitted alone (E). Aggressive interaction between two individuals, with the foreground male emitting territorial calls in response to the background one $(\mathbf{F})$. Red arrows indicate territorial calls. Sound files: Scinax_garbeiAltaFlorestaMT1bPM_AAGm671 (A, D, E); 7679 (FonoZoo) (B); 7806 (FonoZoo) (C); 7808 (FonoZoo) (F). Further recordings details are in Appendix I. 
Table 3. Pairwise comparisons between the three groups of Scinax garbei recognized here, regarding statistical significance (Wilcoxon Mann Whitney Rank Sum Test) of call traits indicated as having higher loadings (RF and DAPC) for discrimination among groups. Values are significant when $p<0.05$.

\begin{tabular}{|c|c|c|c|}
\hline Trait / Pair comparison & $\begin{array}{c}\text { Brazil vs. } \\
\text { Southwestern }\end{array}$ & $\begin{array}{c}\text { Brazil vs. } \\
\text { Northwestern }\end{array}$ & $\begin{array}{c}\text { Southwestern vs. } \\
\text { Northwestern }\end{array}$ \\
\hline Call duration & $\begin{array}{c}Z=2.8723 \\
p<0.007\end{array}$ & $\begin{array}{c}Z=2.9646 \\
p<0.007\end{array}$ & $\begin{array}{c}\mathrm{Z}=-3.1202 \\
p<0.006\end{array}$ \\
\hline Mid-portion pulse interval & $\begin{array}{c}Z=-2.6029 \\
p<0.01\end{array}$ & $\begin{array}{c}Z=2.9277 \\
p<0.007\end{array}$ & $\begin{array}{c}Z=-3.2404 \\
p<0.004\end{array}$ \\
\hline Pulse rate & $\begin{array}{c}Z=2.3548 \\
p<0.02\end{array}$ & $\begin{array}{c}Z=-2.9277 \\
p<0.007\end{array}$ & $\begin{array}{c}Z=3.2404 \\
p<0.004\end{array}$ \\
\hline Final portion pulse interval & $\begin{array}{c}Z=-2.1962 \\
p<0.03\end{array}$ & $\begin{array}{c}Z=2.9358 \\
p<0.007\end{array}$ & $\begin{array}{c}Z=-3.2433 \\
p<0.004\end{array}$ \\
\hline Dominant frequency of the LFB & $\begin{array}{c}\mathrm{Z}=-2.842 \\
p<0.01\end{array}$ & $\begin{array}{c}\mathrm{Z}=-2.9358 \\
p<0.01\end{array}$ & $\begin{array}{c}\mathrm{Z}=-1.1593 \\
p>0.2\end{array}$ \\
\hline Dominant frequency of the HFB & $\begin{array}{c}Z=-2.842 \\
p<0.02\end{array}$ & $\begin{array}{c}Z=-2.7813 \\
p<0.02\end{array}$ & $\begin{array}{c}Z=-1.273 \\
p>0.2\end{array}$ \\
\hline
\end{tabular}

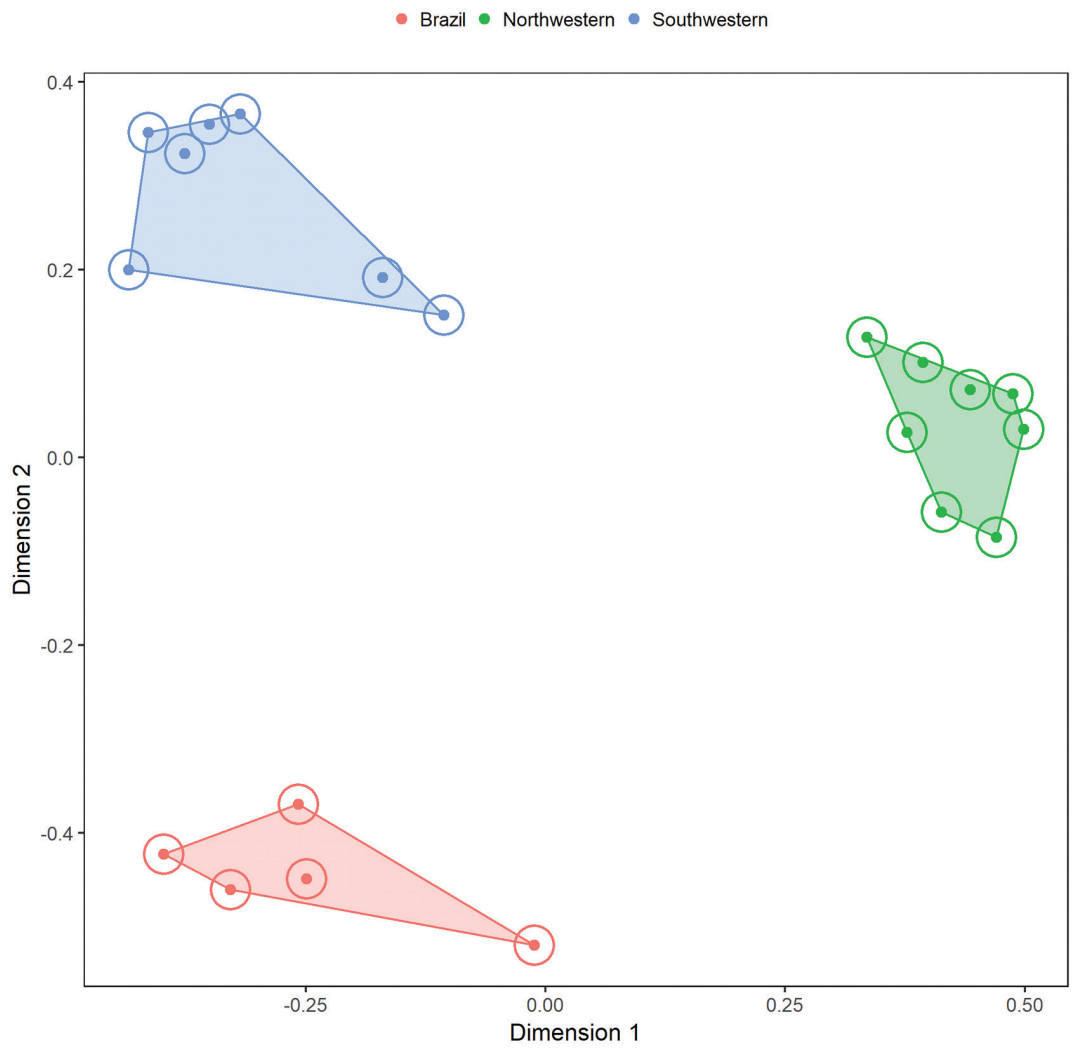

Figure 5. Plots of the two first axes of a Multidimensional Scaling (MDS) on the Random Forest result for advertisement call data of the three groups of Scinax garbei recognized here. 
Call duration

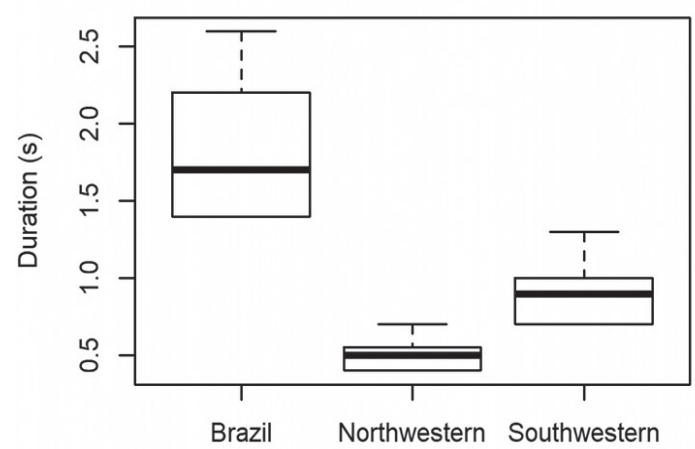

Pulse rate

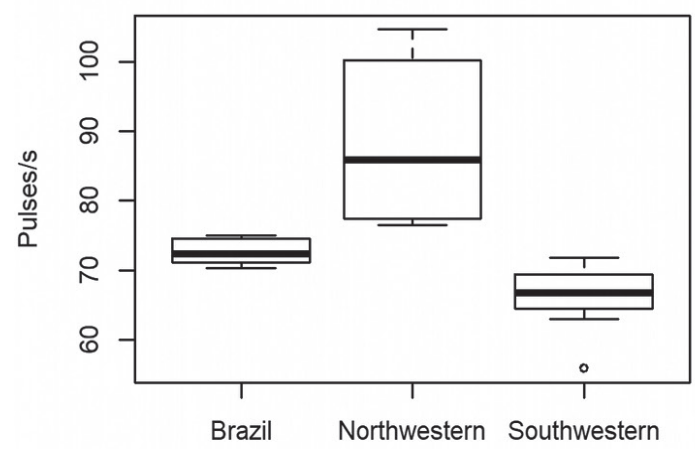

Dominant frequency of the LFB

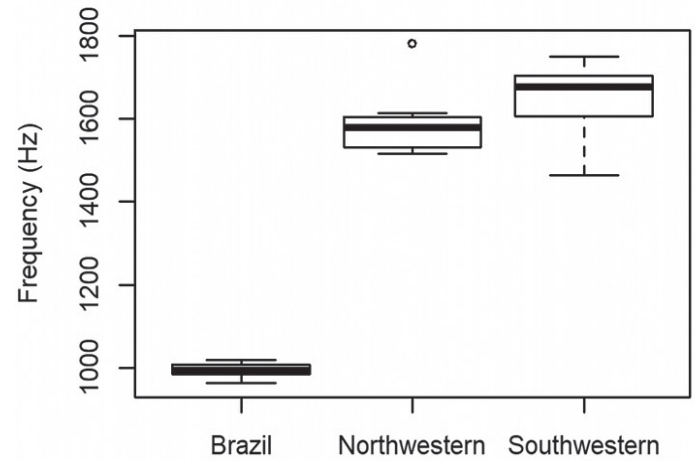

Middle portion pulses interval

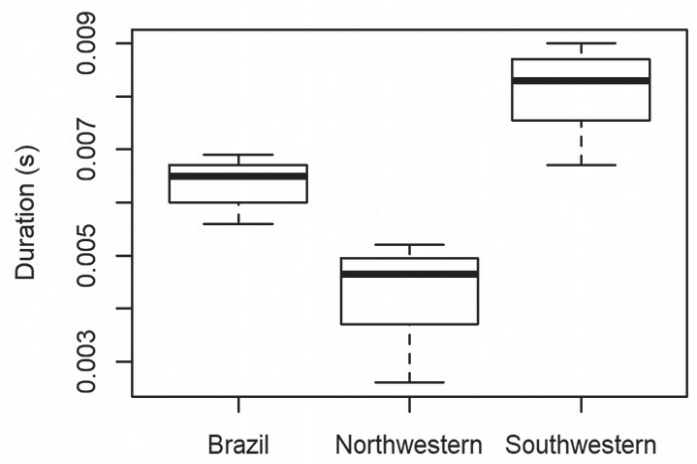

Final pulses interval

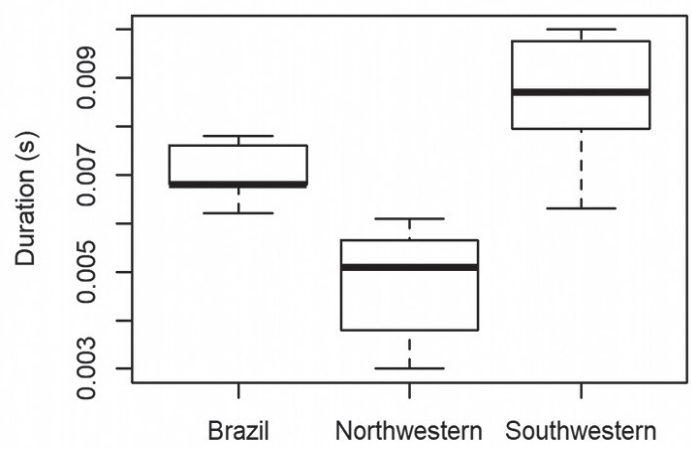

Dominant frequency of the HFB

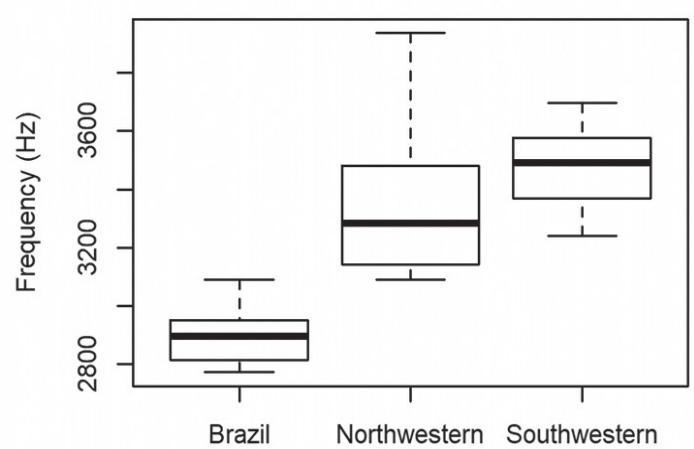

Figure 6. Boxplots of the most important acoustic traits to discrimination among the three groups of Scinax garbei recognized here. See Table 3 for statistical significance values of each trait. 
Duellman (1970) first described the advertisement call of the species (as Hyla garbei) from Santa Cecilia (Ecuador); these call values appeared again in Duellman $(1972,1978)$ and Duellman and Wiens (1993). However, in Duellman and Pyles' (1983) description of the call from Santa Cecilia, there are substantial differences in the values for call rate, pulse rate, and fundamental and dominant frequencies relative to previous studies. Duellman (1972) also reported on the call of a population from Pilcopata (Peru) (as Hyla epacrorhina), and Duellman and Wiens (1993) reported on the call of a population from Tambopata (Peru). The calls of these Peruvian populations resemble one another (except for differences in pulse rate), and differ in call duration, pulse rate, and dominant frequency from the calls of the Ecuadorian populations. In addition, Zimmerman (1983) reported values for pulse rate and dominant frequency for a frog from Manaus (Brazil) that differ from previous works. De la Riva et al. (1994) reported on the advertisement call from Puerto Almacén (Bolivia), and pointed out that their data are substantially different from those of Ecuadorian populations regarding call duration, call rate, pulse rate and dominant frequency. The call data for frogs from Puerto Almacén do not match those for frogs from Brazil, but are quite similar to those reported for Peruvian populations (except for some differences in pulse rate). Duellman (2005) provided some call values for a frog population at the Reserva Cusco Amazónico (Peru); these are mostly consistent with data reported for the Bolivian and other Peruvian populations.

The call values we obtained in our reanalyses of recordings from Pilcopata, Puerto Almacén, and Santa Cecilia, for the most part match the values provided by previous studies, except for the strikingly higher pulse rate (195240 pulses/s vs. 76-103 pulses/s in our study) and the strikingly lower fundamental frequency (391-482 Hz vs. $1500-1781 \mathrm{~Hz}$ of LFB in our study) respectively found by Duellman (1970) and Duellman and Pyles (1983), for the population from Santa Cecilia. Our call values for the population from Manaus differ from those reported by Zimmerman (1983) in dominant frequency $(2350 \mathrm{~Hz}$ vs. $1007 \mathrm{~Hz}$ of LFB and $2894 \mathrm{~Hz}$ of HFB in our study) and pulse rate (100 pulses/s vs. 75 pulses/s in our study). Also, our call values for the population from Tambopata differ from those reported by Duellman and Wiens (1993) in pulse rate (110 pulses/s vs. 63 pulses/s in our study). Most of these discrepancies may reflect the technology employed in call recordings and analyses.

Our multivariate analyses separate the populations of $S$. garbei into three main groups with distinct advertisement calls. Scinax garbei Southwestern and S. garbei Northwestern are diagnosed from each other only by temporal call traits, whereas $S$. garbei Brazil is diagnosed from the other two groups by both temporal and spectral call traits. Besides quantitative call differences, the call of $S$. garbei Northwestern has temporal and spectral structures quite distinct from those of the other groups (Figure 2). Although there are statistically significant differences in both minimum and maximum frequencies of $S$. garbei Brazil in relation to the other groups, we do not consider these traits as diagnostic because the calls may have been affected by the normalization (Materials and Methods).

Although Duellman (1972) reported that the advertisement call of Scinax garbei from Pilcopata was followed by one or two secondary notes, we concluded that these notes are territorial calls. The population from Alta Floresta had the highest emission rate of territorial calls; this can be explained by the high density of males in close-range interactions (Allan 1973, Toledo et al. 2015). Despite being alone, the individual from Manaus also emitted territorial calls, although at a lower rate (as occurs in other species of Scinax; pers. obs. of the authors). Territorial calls of the different groups share a somewhat similar envelope shape, but vary in duration, amplitude modulation levels, and values of spectral traits. 
Although variation in advertisement calls might occur intra-specifically (e.g., Castellano et al. 2002, Heyer and Reid 2003, Smith et al. 2003, Velásquez et al. 2013, Forti et al. 2017, Zaracho et al. 2018), the call divergences we report exceed those usually reported for intraspecific variation. These call differences, along with previous studies reporting on morphological (e.g., Duellman 1972, Heyer 1977, Duellman and Wiens 1993) and molecular (Jansen et al. 2011, Ron et al. 2018) divergences in this species, provide strong evidence that $S$. garbei may represent a complex of up to three species. Thus, this may be another case of what was assumed to be a widely distributed species representing a species complex, as has been recently demonstrated for other Amazonian frog and salamander species (e.g., Jungfer et al. 2010, Simões et al. 2010, Caminer and Ron 2014, Gehara et al. 2014, Caminer et al. 2017, Rivadeneira et al. 2018, Jaramillo et al. 2020).

If more than one species exists within Scinax garbei, there are two names available for two of the populations sampled herein. One is Hyla lutzi, described by Melin (1941) based on two specimens from Manaus and "Rio Uaupés" (São Gabriel da Cachoeira), state of Amazonas, Brazil. After examining the holotype of $S$. garbei and syntypes of $H$. lutzi, together with a series of specimens from the upper Amazon Basin, Duellman (1970) concluded that despite a minor difference in size between Brazilian and Ecuadorian specimens all of them corresponded to a single taxon, and therefore synonymized $H$. lutzi with $S$. garbei. The other synonym of $S$. garbei is $S$. epacrorhina, described by Duellman (1972) from Pilcopata, Cusco Department, Peru. After examining the type series of S. epacrorhina and several specimens from Ecuador and Peru, Duellman and Wiens (1993) concluded that morphological and call differences between these species reflected geographic variation, and therefore synonymized it with $S$. garbei. Given our new data and the historical background, a taxonomic revision including specimens and DNA sequences from localities within the regions sampled here, in addition to data from topotypes, is necessary to elucidate the taxonomic status of the different populations currently assigned to $S$. garbei.

\section{Acknowledgments}

The Associate Editor Philippe J. R. Kok, Jörn Köhler, and an anonymous reviewer helped to improve the drafts of this work. The following researchers made available recordings: William E. Duellman (recordings from Pilcopata and Santa Cecilia), Ignacio De la Riva (recording from Puerto Almacén), J. M. Padial (recordings from Abel Iturralde, Leticia and Pucaurquillo), and T. R. Carvalho (recordings from Manaus). Fonoteca Zoologica from Museo de Ciencias Naturales de Madrid allowed us to have access to the non-Brazilian recordings, and Laura González for all the help in the loan process. CNPq (Conselho Nacional de Desenvolvimento Científico e Tecnológico) supports the research of AAG (300903/2015-4 and 305169/2019-0). CNPq provides a M.Sc. fellowship to AGL (process \#130380/2020-2). CAPES (Coordenação de Aperfeiçoamento de Pessoal de Nível Superior) provides a M.Sc. fellowship to PM (process \#88887.201356/2018-00). FAPESP (Fundação de Amparo à Pesquisa do Estado de São Paulo) provides a Ph.D. fellowship to DLB (process \#2017/27137-7). The collection permit was issued by ICMBIO/SISBIO (30059-12). The Cornell Lab of Ornithology (Bioacoustics Research Program) provided a free license of Raven Pro 1.5 software.

\section{References}

Allan, D. M. 1973. Some relationships of vocalization to behavior in the Pacific treefrog, Hyla regilla. Herpetologica 29: 366-371.

Archer, E. 2014. rfPermute: Estimate Permutation p-values for Random Forest Importance Metrics. Version 1.6.1 [package of R software]. URL: http://CRAN.R-project. org/package=rfPermute.

Audacity Team. 2020. Audacity(R): Free Audio Editor and Recorder. Version 2.4.1. URL: https://audacityteam.org/ 
Ávila-Pires, T. C. S., M. S. Hoogmoed, and W. A. D. Rocha. 2010. Notes on the Vertebrates of northern Pará, Brazil: a forgotten part of the Guianan Region, I. Herpetofauna. Boletim do Museu Paraense Emílio Goeldi Ciências Naturais 5: 13-112.

Baldo, D., K. Araujo-Vieira, D. Cardozo, C. Borteiro, F. Leal, M. O. Pereyra, F. Kolenc, M. L. Lyra, P. C. A. Garcia, C. F. B. Haddad, and J. Faivovich. 2019. A review of the elusive bicolored iris Snouted Treefrogs (Anura: Hylidae: Scinax uruguayus group). PLoS ONE 14: $\mathrm{e} 0222131$.

Bang, D. L. and A. A. Giaretta. 2016. Redescription of the advertisement calls of Scinax tigrinus and Scinax maracaya (Anura: Hylidae) and an evaluation of their differential diagnosis. Revista Brasileira de Biociências 14: $181-186$.

Barrio-Amorós, C. L., F. J. M. Rojas-Runjaic, and J. C. Señaris. 2019. Catalogue of the amphibians of Venezuela: illustrated and annotated species list, distribution, and conservation. Amphibian and Reptile Conservation 13: 1-198.

Bernarde, P. S. 2007. Ambientes e temporada de vocalização da anurofauna no município de Espigão do Oeste, Rondônia, sudoeste da Amazônia: Brasil (Amphibia: Anura). Biota Neotropica 7: 87-92.

Bernarde, P. S., R. A. Machado, and L. C. B. Turci. 2011. Herpetofauna da área do Igarapé Esperança na Reserva Extrativista Riozinho da Liberdade, Acre-Brasil. Biota Neotropica 11: 117-144.

Bernarde, P. S., S. de Albuquerque, D. B. de Miranda, and L. C. B. Turci. 2013. Herpetofauna da floresta do baixo rio Moa em Cruzeiro do Sul, Acre-Brasil. Biota Neotropica 13: 219-244.

Breiman, L. 2001. Random forests. Machine Learning 45: 5-32.

Caminer, M. A. and S. R. Ron. 2014. Systematics of treefrogs of the Hypsiboas calcaratus and Hypsiboas fasciatus species complex (Anura, Hylidae) with the description of four new species. Zookeys 370: 1-68.

Caminer, M. A. and S. R. Ron. 2020. Systematics of the Boana semilineata species group (Anura: Hylidae), with a description of two new species from Amazonian Ecuador. Zoological Journal of the Linnean Society: 1-32.

Caminer, M. A., B. Mila, M. Jansen, A. Fouquet, P. J. Venegas, G. Chávez, S. C. Lougheed, and S. R. Ron. 2017. Systematics of the Dendropsophus leucophyllatus species complex (Anura: Hylidae): Cryptic diversity and the description of two new species. PLOS ONE 12: $\mathrm{e} 0171785$

Carvalho, T. R., A. Angulo, M. N. Kokubum, D. A. Barrera, M. B. de Souza, C. F. B. Haddad, and A. A. Giaretta.
2019. A new cryptic species of the Adenomera andreae Clade from southwestern Amazonia (Anura, Leptodactylidae). Herpetologica 75: 233-246.

Carvalho, T. R., P. Azarak, D. Bang, W. E. Duellman, and A. A. Giaretta. 2017. A reassessment of the vocalization and distribution of Scinax exiguus (Duellman, 1986) (Anura: Hylidae) in the Amazonian savanna of Roraima, northern Brazil, with the description of its aggressive call. Neotropical Biodiversity 3: 196-202.

Castellano, S., B. Cuatto, R. Rinella, A. Rosso, and C. Giacoma. 2002. The advertisement call of the European treefrogs (Hyla arborea): a multilevel study of variation. Ethology 108: 75-89.

Center for Conservation Bioacoustics. 2014. Raven Pro: Interactive Sound Analysis Software. Version 1.5. URL: http://ravensoundsoftware.com.

Chasiluisa, V. D., M. A. Caminer, A. Varela-Jaramillo, and S. R. Ron. 2020. Description and phylogenetic relationships of a new species of treefrog of the Osteocephalus buckleyi species group (Anura: Hylidae). Neotropical Biodiversity 6: 21-36.

Cocroft, R., V. R. Morales, and R. W. McDiarmid. 2001. Frogs of Tambopata, Peru. Ithaca. Macaulay Library of Natural Sounds, Cornell Laboratory of Ornithology. Track 40 (Scinax garbei) [CD audio].

De la Riva, I., R. Márquez, and J. Bosch. 1994. Advertisement calls of Bolivian species of Scinax (Amphibia, Anura, Hylidae). Bijdragen tot de Dierkunde 64: 75-85.

Duellman, W. E. 1970. Identity of the South American hylid frog Garbeana garbei. Copeia 1970: 534-538.

Duellman, W. E. 1972. South American frogs of the Hyla rostrata group (Amphibia, Anura, Hylidae). Zoologische Mededelingen 47: 177-192.

Duellman, W. E. 1978. The Biology of an Equatorial Herpetofauna in Amazonian Ecuador. Lawrence. University of Kansas. 352 pp.

Duellman, W. E. 1999. Patterns of Distribution of Amphibians: A Global Perspective. Baltimore. Johns Hopkins University Press. 633 pp.

Duellman, W. E. 2005. Cusco Amazónico: The Lives of Amphibians and Reptiles in an Amazonian Rainforest. Ithaca. Comstock Publishing Associates. 456 pp.

Duellman, W. E. and J. J. Wiens. 1993. Hylid frogs of the genus Scinax Wagler, 1830, in Amazonian Ecuador and Peru. Occasional Papers of the Museum of Natural History, The University of Kansas 153: 1-57.

Duellman, W. E. and L. Trueb. 1994. Biology of Amphibians. Baltimore. Johns Hopkins University Press. 670 pp.

Duellman, W. E. and R. A. Pyles. 1983. Acoustic resource partitioning in anuran communities. Copeia 1983: 639_ 649. 
Faivovich, J. 2002. A cladistic analysis of Scinax (Anura: Hylidae). Cladistics 18: 367-393.

Faivovich, J., C. F. B. Haddad, P. C. A. Garcia, D. R. Frost, J. A. Campbell, and W. C. Wheeler. 2005. Systematic review of the frog family Hylidae, with special reference to Hylinae: phylogenetic analysis and taxonomic revision. Bulletin of the American Museum of Natural History 2005: 1-240.

Ferrão, M., O. Colatreli, R. Fraga, I. L. Kaefer, J. Moravec, and A. P. Lima. 2016. High species richness of Scinax treefrogs (Hylidae) in a threatened Amazonian landscape revealed by an integrative approach. PLOS ONE 11: $\mathrm{e} 0165679$.

Forti, L. R., R. Lingnau, and J. Bertoluci. 2017. Acoustic variation in the advertisement call of the Lime treefrog Sphaenorhynchus caramaschii (Anura: Hylidae). Vertebrate Zoology 67: 197-205.

Fouquet, A., A. Gilles, M. Vences, C. Marty, M. Blanc, and N. J. Gemmell. 2007. Underestimation of species richness in Neotropical frogs revealed by mtDNA analyses. PLOS ONE 2: e1109.

Fouquet, A., Q. Martinez, L. Zeidler, E. A. Courtois, P. Gaucher, M. Blanc, J. D. Lima, S. M. Souza, M. T. Rodrigues, and P. J. R. Kok. 2016. Cryptic diversity in the Hypsiboas semilineatus species group (Amphibia, Anura) with the description of a new species from the eastern Guiana Shield. Zootaxa 4084: 79-104.

Frost, D. R. 2020. (ed.). Amphibian Species of the World: an Online Reference. Version 6.1. Electronic Database accessible at https://amphibiansoftheworld.amnh.org/ index.php_American Museum of Natural History, New York, USA. Captured on 23 April 2020.

Funk, W. C., M. Caminer, and S. R. Ron. 2011. High levels of cryptic species diversity uncovered in Amazonian frogs. Proceedings of the Royal Society B, Biological Sciences 279: 1806-1814.

Gehara, M., A. J. Crawford, V. G. D. Orrico, A. Rodríguez, S. Lötters, A. Fouquet, L. S. Barrientos, F. Brusquetti, I. De la Riva, R. Ernst, G. G. Urrutia, F. Glaw, J. M. Guayasamin, M. Hölting, M. Jansen, P. J. R. Kok, A. Kwet, R. Lingnau, M. Lyra, J. Moravec, J. P. Pombal Jr, F. J. M. Rojas-Runjaic, A. Schulze, J. C. Señaris, M. Solé, M. T. Rodrigues, E. Twomey, C. F. B. Haddad, M. Vences, J. Köhler. 2014. High levels of diversity uncovered in a widespread nominal taxon: continental phylogeography of the Neotropical tree frog Dendropsophus minutus. PLoS ONE 9: e103958.

Heyer, W. R. 1977. Taxonomic notes on frogs from the Madeira and Purus rivers, Brasil. Papéis Avulsos de Zoologia 8: 141-162.

Heyer, W. R. and Y. R. Reid. 2003. Does advertisement call variation coincide with genetic variation in the genetically diverse frog taxon currently known as
Leptodactylus fuscus (Amphibia: Leptodactylidae)? Anais da Academia Brasileira de Ciências 75: 39-54.

Hothorn, T., K. Hornik, M. A. van de Wiel, and A. Zeileis. 2008. Implementing a Class of Permutation Tests: the coin Package. Journal of Statistical Software 28: 1-23.

Jansen, M., R. Bloch, A. Schulze, and M. Pfenninger. 2011. Integrative inventory of Bolivia's lowland anurans reveals hidden diversity. Zoologica Scripta 40: 567583.

Jaramillo, A. F., I. De la Riva, J. M. Guayasamin, J. C. Chaparro, G. Gagliardi-Urrutia, R. Gutiérrez, I. Brcko, C. Vilà, and S. Castroviejo-Fisher. 2020. Vastly underestimated species richness of Amazonian salamanders (Plethodontidae: Bolitoglossa) and implications about plethodontid diversification. Molecular Phylogenetics and Evolution: 106841.

Jombart, T. 2008. Adegenet: a R package for the multivariate analysis of genetic markers. Bioinformatics 24: 1403 1405.

Jombart, T., S. Devillard, and F. Balloux. 2010. Discriminant analysis of principal components: a new method for the analysis of genetically structured populations. $B M C$ Genetics 11: 1-15.

Jungfer, K. H., S. Reichle, and O. Piskurek. 2010. Description of a new cryptic southwestern Amazonian species of leaf-gluing treefrog, genus Dendropsophus (Amphibia: Anura: Hylidae). Salamandra 46: 204-213.

Köhler, J., M. Jansen, A. Rodríguez, P. J. R. Kok, L. F. Toledo, M. Emmrich, F. Glaw, C. F. B. Haddad, M-O. Rödel, and M. Vences. 2017. The use of bioacoustics in anuran taxonomy: theory, terminology, methods and recommendations for best practice. Zootaxa 4251: 1-124.

La Marca, E. 1992. Catálogo Taxonómico, Biogeográfico y Bibliográfico de las Ranas de Venezuela. Volume 9. Merida. Universidad de los Andes, Facultad de Ciencias Forestales, Unidad de Producción. 197 pp.

Liaw, A. and M. Wiener. 2002. Classification and regression by randomForest. $R$ News 2: 18-22.

Lima, A. P., W. E. Magnusson, M. Menin, L. K. Erdtmann, D. J. Rodrigues, C. Keller, and W. Hödl. 2006. Guia de Sapos da Reserva Adolpho Ducke, Amazonia Central. Manaus. Áttema Design Editorial. 168pp.

Melin, D. 1941. Contribution to the knowledge of the Amphibia of South America. Meddelanden från Götesborgs Musei Zoologiska Avdelining 88: 1-71.

Miranda-Ribeiro, A. de. 1926. Notas para servirem ao estudo dos gymnobatrachios (Anura) Brasileiros. Archivos do Museu Nacional do Rio de Janeiro 27: 1-227.

Mota, E. P., I. L. Kaefer, M. S. Nunes, A. P. Lima, and I. P. Farias. 2020. Hidden diversity within the broadly distributed Amazonian giant monkey frog (Phyllomedusa bicolor: Phyllomedusidae). Amphibia-Reptilia: 1-11. 
Noronha, J. C., M. M. Lima, C. L. Velasquez, E. J. Almeida, A. B. Barros, and D. J. Rodrigues. 2015. Update das espécies de anuros da Fazenda São Nicolau, Mato Grosso, Brasil. Scientific Electronic Archives 8: 15-25.

Nunes, I., A. Kwet, and J. P. Pombal Jr. 2012. Taxonomic revision of the Scinax alter species complex (Anura: Hylidae). Copeia 2012: 554-569.

Padial, J. M. and I. De la Riva. 2009. Integrative taxonomy reveals cryptic Amazonian species of Pristimantis (Anura: Strabomantidae). Zoological Journal of the Linnean Society 155: 97-122.

Pantoja, D. and R. de Fraga. 2012. Herpetofauna of the Reserva Extrativista do Rio Gregório, Juruá Basin, southwest Amazonia, Brazil. Check List 8: 360-374.

Piatti, L., P. M. O. de Amaro, J. F. J. Araújo, V. Q. A. Sanches, and P. S. Bernarde. 2012. Anurans of a disturbed area in Jarú, Rondônia, Brazil. Check List 8: $83-87$.

Pinheiro, L. C., Y.O.C. Bitar, U. Galatti, S. Neckel-Oliveira, and M.C. dos Santos-Costa. 2012. Amphibians from southeastern state of Pará: Carajás Region, northern Brazil. Check List 8: 693-702.

R Core Team. 2018. R: a language and environment for statistical computing. Version 3.5.2. URL: http:// www.R-project.org. Captured on 24 apr 2019.

Rivadeneira, C. D., P. J. Venegas, and S. R. Ron. 2018. Species limits within the widespread Amazonian treefrog Dendropsophus parviceps with descriptions of two new species (Anura, Hylidae). ZooKeys 726: 2577.

Ron, S. R., W. E. Duellman, M. A. Caminer, and D. Pazmino. 2018. Advertisement calls and DNA sequences reveal a new species of Scinax (Anura: Hylidae) on the Pacific lowlands of Ecuador. PLOS ONE 13: e0203169.

São-Pedro, V. A., H. C. Costa, and R. N. Feio. 2009. A Herpetofauna do AHE Dardanelos, Aripuanã, Mato Grosso. Viçosa. Universidade Federal de Viçosa, Museu de Zoologia João Moojen. 42 pp.

Silva-e-Silva, Y. B. and C. E. Costa-Campos. 2014. Scinax garbei (Miranda-Ribeiro, 1926) (Amphibia: Anura: Hylidae): distribution extension for Brazilian Amazonia and first record in the state of Amapá. Check List 10: $448-449$.

Simões, P. I., A. P. Lima, and I. Farias. 2010. The description of a cryptic species related to the pan-Amazonian frog Allobates femoralis. Zootaxa 2406: 1-28.

Smith, M. J., W. Osborne, and D. Hunter. 2003. Geographic variation in the advertisement call structure of Litoria verreauxii (Anura: Hylidae). Copeia 2003: 750-758.
Sueur, J., T. Aubin, and C. Simonis. 2008. Seewave, a free modular tool for sound analysis and synthesis. Bioacoustics 18: 213-226.

Toledo, L. F., I. A. Martins, D. P. Bruschi, M. A. Passos, C. Alexandre, and C. F. B. Haddad. 2015. The anuran calling repertoire in the light of social context. Acta Ethologica 18: 87-99.

Vacher, J.-P., J. Chave, F. G. Ficetola, G. Sommeria-Klein, S. Tao, C. Thébaud, M. Blanc, A. Camacho, J. Cassimiro, T. J. Colston, M. Dewynter, R. Ernst, P. Gaucher, J. O. Gomes, R. Jairam, P. J. R. Kok, J. D. Lima, Q. Martinez, C. Marty, B. P. Noonan, P. M. S. Nunes, P. Ouboter, R. Recoder, M. T. Rodrigues, A. Snyder, S. Marques-Souza, and A. Fouquet. 2020. Large-scale DNA-based survey of frogs in Amazonia suggests a vast underestimation of species richness and endemism. Journal of Biogeography: 1-11.

Vacher, J.-P., P. J. R. Kok, M. T. Rodrigues, J. D. Lima, A. Lorenzini, Q. Martinez, M. Fallet, E. A. Courtois, M. Blanc, P. Gaucher, M. Dewynter, R. Jairam, P. Ouboter, C. Thébaud, and A. Fouquet. 2017. Cryptic diversity in Amazonian frogs: integrative taxonomy of the genus Anomaloglossus (Amphibia: Anura: Aromobatidae) reveals a unique case of diversification within the Guiana Shield. Molecular Phylogenetics and Evolution 112: 158-173.

Velásquez, N.A., J. Marambio, E. Brunetti, M. A. Méndez, R. A. Vásquez, and M. Penna. 2013. Bioacoustic and genetic divergence in a frog with a wide geographical distribution. Biological Journal of the Linnean Society 110: $142-155$.

Villalobos, F., R. Dobrovolski, D. B. Provete, and S. F. Gouveia. 2013. Is rich and rare the common share? Describing biodiversity patterns to inform conservation practices for South American anurans. PLOS ONE 8: e56073.

Wells, K. D. 2007. The Ecology and Behavior of Amphibians. Chicago. The University of Chicago Press. 1400 pp.

Wiens, J. J., C. A. Kuczynski, X. Hua, and D. S. Moen. 2010. An expanded phylogeny of treefrogs (Hylidae) based on nuclear and mitochondrial sequence data. Molecular Phylogenetics and Evolution 55: 871-882.

Zaracho, V. H., L . D. Aguiar, and A. A. Giaretta. 2018. Geographic variation in the advertisement call of Trachycephalus typhonius Anura: Hylidae based on South American samples. Zootaxa 4521: 404-416.

Zimmerman, B. L. 1983. A comparison of structural features of calls of open and forest habitat frog species in the central Amazon. Herpetologica 39: 235-246.

Editor: Philippe J. R. Kok 


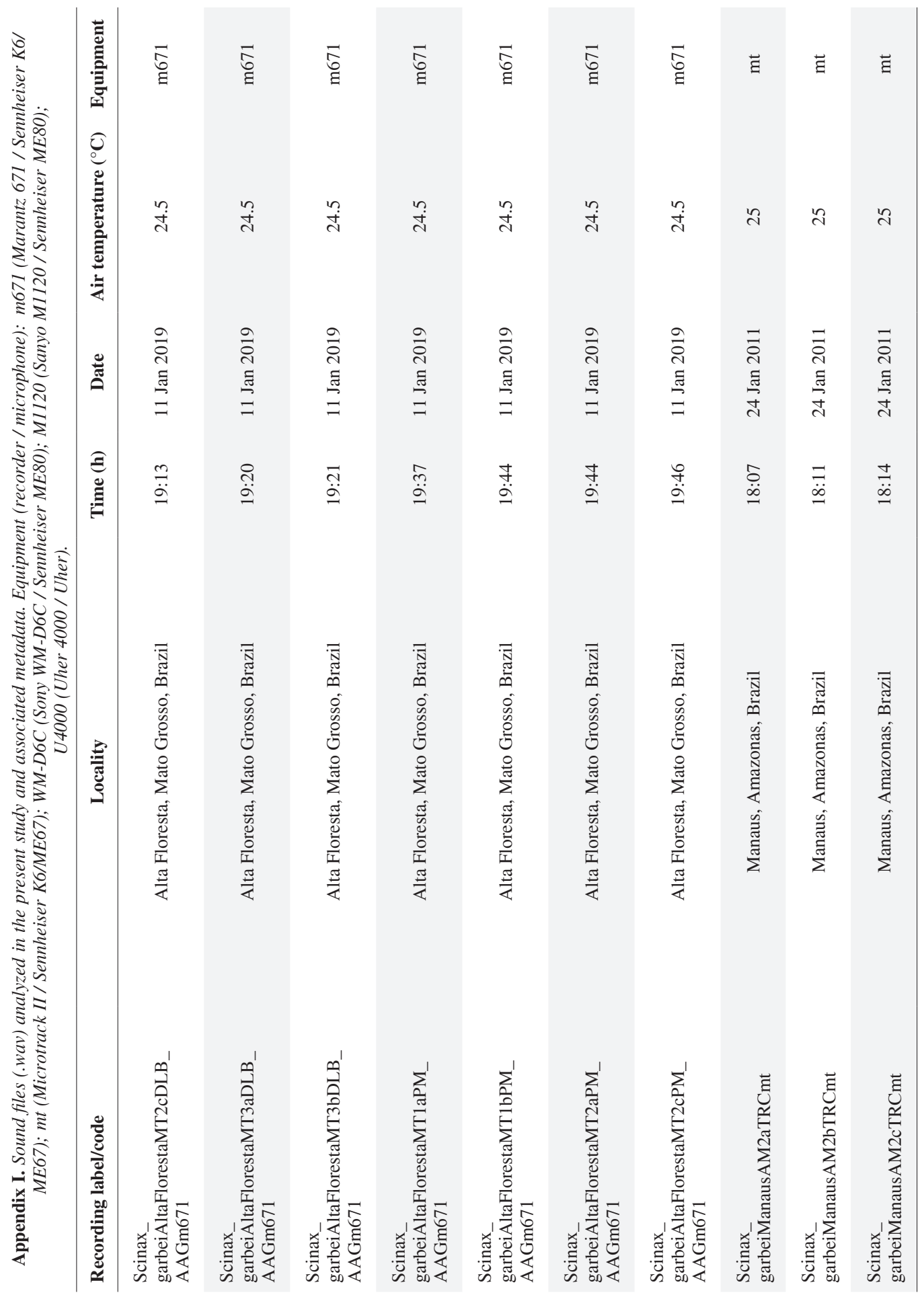




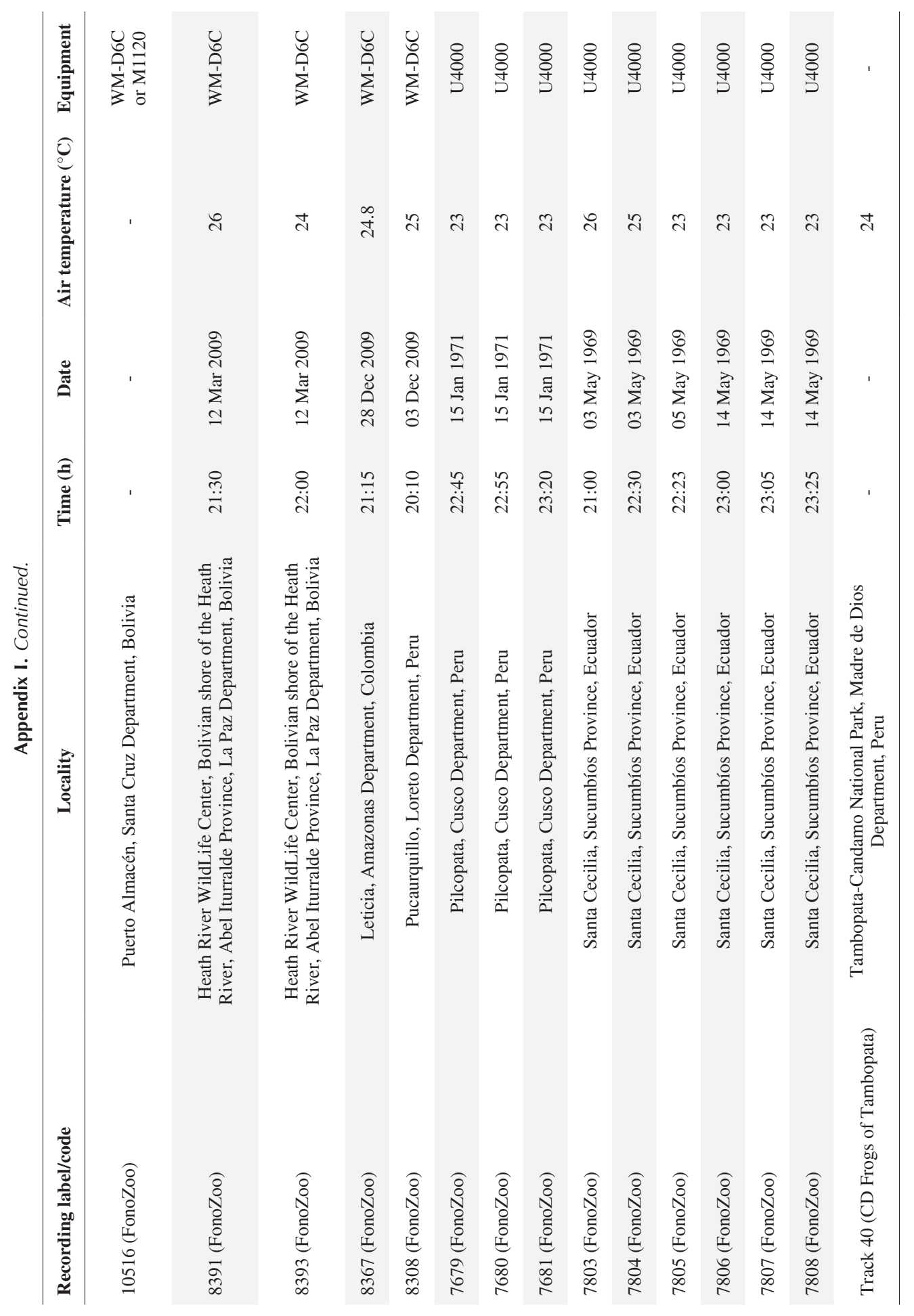




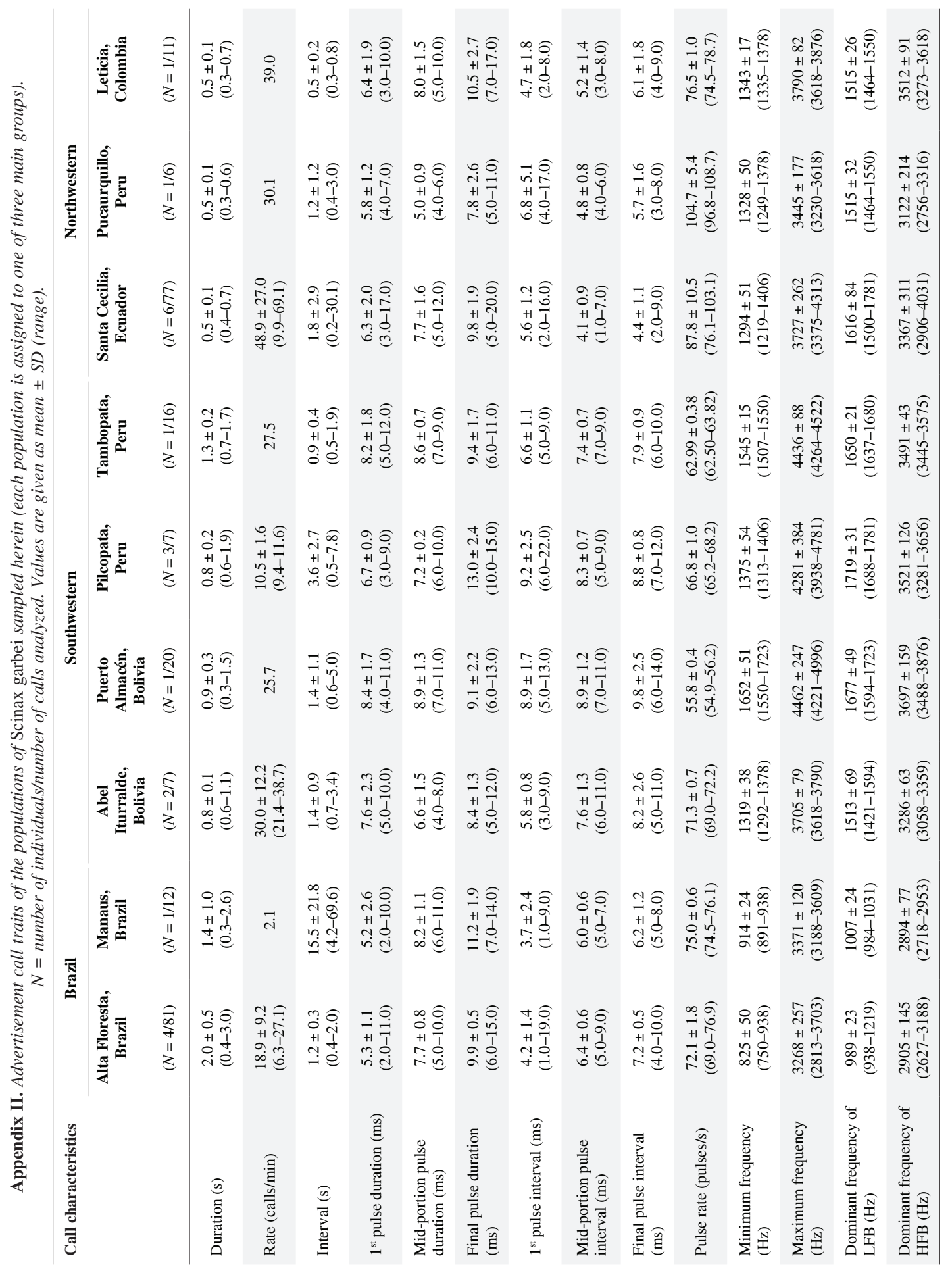

